\title{
Organic aggregates in detrital food webs: incorporation by bay scallops Argopecten irradians
}

\author{
Merryl Alber ${ }^{1}$, Ivan Valiela ${ }^{2}$ \\ ${ }^{1}$ Marine Sciences Department, University of Georgia, Athens, Georgia 30602, USA \\ ${ }^{2}$ Boston University Marine Program, Marine Biological Laboratory, Woods Hole, Massachusetts 02543, USA
}

\begin{abstract}
Bay scallops Argopecten irradians were fed organic aggregates produced from the dissolved organic material (DOM) released from 5 species of marine macrophytes (Fucus vesiculosis, Ulva lactuca, Gracilaria tikvahiae, Spartina alterniflora, Zostera marina). The detrital food web pathway from macrophytes to scallops via aggregates was traced with ${ }^{15} \mathrm{~N}$ and compared with nitrogen incorporation via direct absorption of DOM or consumption of morphous detrital particles, which are fragments of the original material. All 3 sources of $\mathrm{N}$ were fed to scallops for 4 to $24 \mathrm{~h}$ in a laboratory flow-through system. In all cases, scallops incorporated little or no nitrogen when fed DOM or morphous detritus $\left\{\leq 20 \mu \mathrm{g} \mathrm{N} \mathrm{g}^{-1}\right.$ dry wt $\mathrm{h}^{-1}$ ), but ranged from 56 to $133 \mu \mathrm{g} \mathrm{N} \mathrm{g}^{-1}$ dry wt $\mathrm{h}^{-1}$ when fed aggregates. Nitrogen uptake was linearly related to the amount of time scallops were fed aggregates $\left(r^{2}=0.87\right)$, regardless of the macrophyte source of the DOM. We interpret these data to suggest that labile DOM from any source can potentially be incorporated by metazoan consumers via the aggregate pathway.
\end{abstract}

KEY WORDS: Organic aggregates - Detritus · Food webs · Scallops · Dissolved organic matter Nitrogen

\section{INTRODUCTION}

Bivalves are the dominant suspension feeders in many near-shore environments: individuals can filter up to $10 \mathrm{l}$ of water $\mathrm{g}^{-1}$ dry wt $\mathrm{h}^{-1}$ (Winter 1978). Because filtration rates are so high, bivalves in shallow coastal environments encounter much of the suspended particulate material transported by water, removing some of it as food. In an annual study of the quantity of detrital and phytoplankton particles in Chesapeake Bay, USA, Van Valkenberg et al. (1978) found that, although a phytoplankton bloom during summer accounted for as much as $45 \%$ of the POM (particulate organic matter), POM over the whole year averaged $77 \%$ non-living detritus. In contrast to the seasonal variability in phytoplankton numbers, variation in the number of detrital particles was minimal. In light of the abundance of non-living particles in the water column, bivalves processing water in spatially and temporally heterogeneous coastal environments would benefit if they were able to use detrital material as a food source (Langdon \& Newell 1990).
There are 2 lines of evidence to support the notion that suspension feeders do meet at least part of their nutritional requirements by eating macrophyte detritus. First, stable isotope studies have shown that suspension feeders resemble macrophytes in isotopic composition, suggesting that there are trophic links to macrophytes. Peterson et al. (1985) used stable isotope values to calculate that the diet of ribbed mussels Geukensia demissa living along a creek in Great Sippewissett marsh, Massachusetts, USA, consisted of up to $80 \%$ Spartina alterniflora. Langdon \& Newell (1990) reported similar results in a study in Canary Creek, Delaware Bay, USA, with G. demissa deriving between 30 and $50 \%$ of their carbon and sulphur from $S$. alterniflora. In addition, Duggins et al. (1989) estimated that primary consumers conservatively averaged $58 \%$ kelp-derived carbon in kelp-dominated islands in Alaska. In their study, the $\delta^{13} \mathrm{C}$ value of Mytilus edulis ranged from -17 to $-21 \%$, closer to that of kelp $(-18 \pm 3 \%$ ) than that of phytoplankton $(-24 \pm$ $1 \%$ ) (Simenstad et al. 1993). 
The second line of evidence that bivalves assimilate macrophyte-derived material comes from whole system energy budgets of a kelp bed community off Cape Peninsula, South Africa, where filter feeders account for $77 \%$ of total secondary production and $84 \%$ of consumption (Newell et al. 1982). These investigators concluded that the combined microbial and phytoplankton food resources could at most provide $50 \%$ of the calculated consumption of the community as a whole and suggested that the community depends directly on detritus for the remaining portion of their energetic requirements. A study of the carbon requirements of one of the filter feeders, Choromytilus meridionalis, suggested that kelp detritus is an important carbon source for these mussels even if both phytoplankton and bacteria are used with high efficiency (Seiderer \& Newell 1985)

Despite the above results, however, vascular plant detritus is thought to be poor quality food for suspension feeders (Kirby-Smith 1976, Williams 1981). Langdon \& Newell (1990) estimated that refractory cellulosic detritus derived from Spartina alterniflora could only supply 0.7 and $8.6 \%$ of the carbon requirements of the oyster Crassostrea virginica and the mussel Geukensia demissa, respectively (see also Kreeger et al. 1988, Crosby et al. 1989, 1990). Although detritus derived from macroalgae has been shown to be more available to deposit feeders than material derived from vascular plants (Tenore 1977, Tenore \& Hanson 1980), evidence for the use of macroalgal detritus by suspension feeders is equivocal. We have shown that 2 species of mussels, G. demissa and Mytilus edulis, have very low incorporation rates for particulate detritus derived from Fucus vesiculosis (Alber \& Valiela 1994c). Cranford \& Grant (1990) reported that the sea scallop Placopecten magellanicus had variable absorption efficiencies (0 to $60 \%$ ) when fed fresh kelp detritus and did not appear to readily use the material, but did absorb aged material with an efficiency of $87 \%$. In contrast, Stuart et al. (1982) reported that kelp detritus could be absorbed by the mussel Aulacomya ater with an efficiency of $50 \%$, and saw no difference in assimilation of new versus aged detritus.

One resolution of this paradox - macrophyte derived detritus is used with variable efficiency by suspension feeders, yet isotopic and whole system balances suggest that it is being used as a food source may come through the appreciation that macrophyte detritus is a heterogeneous mixture of materials. Detritus can be morphous, that is, fragmented material that still retains recognizable cellular structure, or it can be amorphous particulate material derived from the aggregation of dissolved organic matter (DOM) released by macrophytes (Bowen 1984). In previous work, the mussels Mytilus edulis and Geukensia demissa incorporated more nitrogen from aggregates than from either DOM or morphous detritus derived from a brown alga, Fucus vesiculosis (Alber \& Valiela $1994 \mathrm{c}$ ). The present study had 2 goals. First, to determine whether our previous results could be generalized to other species of bivalves, we were interested in evaluating whether bay scallops Argopecten irradians also incorporate aggregates better than DOM and morphous detritus. Second, we wanted to compare the incorporation of aggregates formed from different species of macrophytes. Three coastal macroalgae, a red (Gracilaria tikvahiae), a green (Ulva lactuca), and a brown alga (Fucus vesiculosis), and 2 vascular plants, eelgrass Zostera marina and salt marsh cord grass Spartina alterniflora, were used in these experiments. These species were chosen to represent the major groups of coastal macrophytes found in the northeastern U.S. Our expectation was that scallops would differ in their incorporation of aggregates derived from the DOM of different producers. ${ }^{15} \mathrm{~N}$ was used to trace nitrogen from aggregates, DOM, and morphous detritus to scallops.

\section{MATERIALS AND METHODS}

Labelling producers. Macroalgae (Gracilaria tikvahiae, Ulva lactuca, and Fucus vesiculosis) were collected from intertidal areas in Falmouth, Massachusetts, and labelled in batch culture in seawater aquaria. $99.5 \%{ }^{15} \mathrm{~N}$ (Cambridge Isotope Lab, Woburn, MA) was added to the water as ${ }^{15} \mathrm{NH}_{4} \mathrm{Cl}$ every 2 to $3 \mathrm{~d}$ for 9 to $15 \mathrm{~d}$. Zostera marina was transplanted into clay pots that were placed in aquaria, and label was injected directly into the substrate twice weekly for 4 wk. Spartina alterniflora was transplanted into buckets and label was injected into the substrate twice weekly for $11 \mathrm{wk}$. After the labelling period, all material was rinsed in freshwater and freeze-killed $\left(-20^{\circ} \mathrm{C}\right)$.

Labelled aggregate production. Aggregates were produced from macrophytes as previously described (Alber \& Valiela 1994a). Briefly, samples of labelled, dead macrophytes ( 25 to $50 \mathrm{~g}$ wet $\mathrm{wt}$ ) were placed into glass jars containing $500 \mathrm{ml}$ of $0.22 \mu \mathrm{m}$ filtered seawater (FSW) and allowed to leach in the dark at $15^{\circ} \mathrm{C}$ for 3 to $7 \mathrm{~d}$. After the leaching period, the DOM-rich leachate was filtered through Whatman GF/F filters (nominal pore size $0.7 \mu \mathrm{m}$ ), and the filtrate was bubbled with air at $15^{\circ} \mathrm{C}$ in the dark ( 5 to $14 \mathrm{~d}$ ). Aggregates were operationally defined as any organic material caught on GF/F filters after bubbling. Aggregates were present at the end of the bubbling period in all cases. Aggregate samples were filtered onto precombusted $\left(6 \mathrm{~h}, 550^{\circ} \mathrm{C}\right) 0.7 \mu \mathrm{m}$ glass fiber filters, dried 
$\left(60^{\circ} \mathrm{C}\right.$ oven) and stored desiccated for subsequent analysis of atom $\%{ }^{15} \mathrm{~N}$.

Treatment diets. ${ }^{15} \mathrm{~N}$-labelled aggregates, DOM, and morphous detritus produced from each of the 5 macrophyte species were fed to juvenile scallops in a series of short-term experiments conducted in a laboratory flow-through system.

Aggregates were produced as described above. At the end of the bubbling period, jars that had initially contained ${ }^{15} \mathrm{~N}$-labelled DOM now contained a mixture of DOM and aggregates. This mixture was fed as the aggregate diet in experiments, and was delivered so that the concentration of aggregates in experimental tanks would be about $1 \mu \mathrm{g}$ dry wt $\mathrm{ml}^{-1}$. Aggregate dry weight was determined by filtering a known volume ( 5 to $15 \mathrm{ml}$ ) of the aggregate suspension and drying the filter overnight $\left(60^{\circ} \mathrm{C}\right)$. This protocol meant that aggregate concentration during an experimental run was determined based on samples obtained the day before. Actual concentration of the aggregate diets, measured during the experiments, averaged $1.1 \pm 0.3$ (SD) $\mu \mathrm{g}$ dry wt $\mathrm{ml}^{-1}$ for all but Spartina-derived aggregates, whose concentration averaged $2.9 \pm 0.3 \mu \mathrm{g} d r y$ wt $\mathrm{ml}^{-1}$.

Labelled DOM was made by filtering a replicate jar of ${ }^{15} \mathrm{~N}$-labelled aggregates through a GF/F filter (nominal pore size $0.7 \mu \mathrm{m}$ ). Anything that passed through the filter was operationally defined as DOM in this study. The DOM treatment was delivered to tanks at the same flow rate as the corresponding aggregate treatment. The DOM diet therefore served as a control to help distinguish between direct DOM uptake and aggregate uptake in the aggregate treatment.

Morphous detritus was prepared by grinding samples of leached, labelled macrophytes through a $250 \mu \mathrm{m}$ mesh in a Wiley mill. Morphous material was mixed with $0.22 \mu \mathrm{m}$ FSW, and delivered so that the final concentration was about $1 \mu \mathrm{g}$ dry material $\mathrm{ml}^{-1}$ Both DOM and morphous detrital diets were delivered for the same number of hours as the equivalent aggregate suspension. Unfed controls (unlabelled, $0.22 \mu \mathrm{m}$ FSW was delivered instead of food) were run in each experimental trial.

Experimental apparatus. Treatment diets were fed to juvenile scallops in a flow-through system (Fig. 1). The system was constructed so that $0.22 \mu \mathrm{m}$ FSW would flow through the experimental tanks $(20 \mathrm{~cm}$ diameter polyethylene funnels) at a rate of $75 \mathrm{ml} \mathrm{min}^{-1}$. Experimental funnels were stoppered at the bottom and contained a smaller ( $8 \mathrm{~cm}$ diameter) funnel nested inside the larger one. The smaller funnel had $4 \mathrm{~mm}$ mesh nitex screening glued onto the top. The mesh served as a platform to hold experimental scallops, and fecal material and uneaten food fell down into the bottom of the funnel. Funnels were drained through an outlet port positioned at a level that maintained $1 \mathrm{l}$ of water in each funnel.
Treatment diets were held in $4 \mathrm{l}$ glass jars and stirred with magnetic stirrers to keep them in suspension. Diets were dripped from the jars into the funnel via a peristaltic pump. Tubes delivering food were on the opposite side of the funnel from the outlet port. Each funnel contained 2 to 4 scallops and received food from a separate jar.

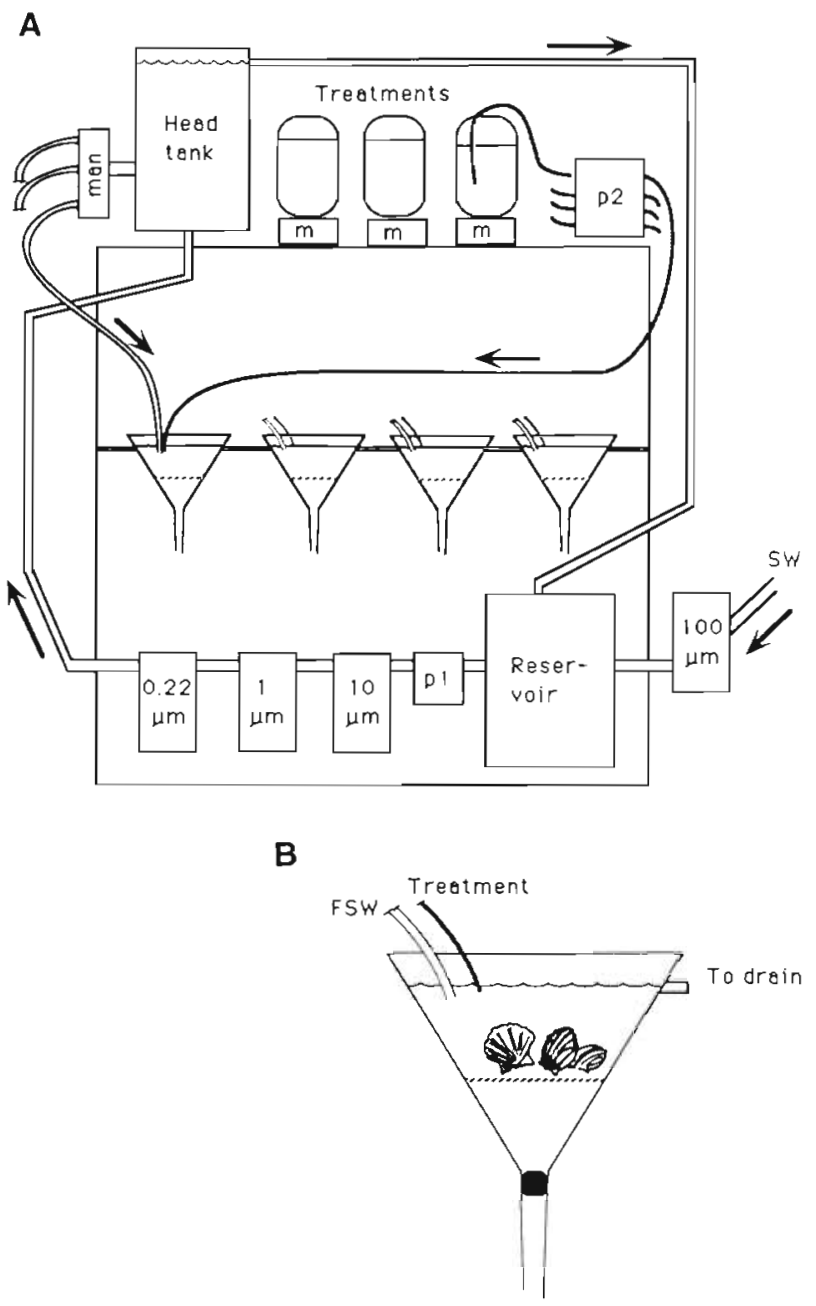

Fig. 1 (A) Diagram of flow-through system used to deliver treatment diets to scallops Argopecten irradians. Incurrent ambient seawater (SW) (open lines) ran through an in-line $100 \mu \mathrm{m}$ filter into the reservoir. Water was pumped by a magnetic drive centrifugal pump (p1) though a series of 3 in-line filters $(10,1,0.22 \mu \mathrm{m})$, up to the head tank, through a manifold (man) and into experimental funnels. Water level in the head tank was kept constant to maintain constant pressure. Overflow water went back into the reservoir Treatment diets (filled lines) were kept in suspension with magnetic stirrers (m), and pumped via a peristaltic pump (p2) into funnels. (B) Diagram of experimental funnel. Both water and treatment diet flowed into the funnels as described above, through an outlet port positioned to maintain the water in the tanks at $1 \mathrm{l}$, and out to drain. Scallops were placed on $4 \mathrm{~mm}$ nitex mesh platforms inside the funnels 
Experimental scallops and protocol. Juvenile scallops were obtained from the Martha's Vineyard Shellfish Hatchery in Vineyard Haven, Massachusetts, and ranged from 20 to $38 \mathrm{~mm}$ and 1 to $9 \mathrm{~g}$ (wet wt). During each trial, experimental individuals ( 2 to 12 scallops per treatment diet) were placed into the system and first fed unlabelled diatoms (Thalassiosira weissflogii) for $48 \mathrm{~h}$. Next, treatment diets (labelled aggregates, DOM, morphous detritus; FSW) were delivered for periods ranging from 5 to $24 \mathrm{~h}$. The amount of labelled aggregates produced from each macrophyte species was variable, and constrained both the number of scallops fed each diet and the duration of a given experimental trial. Aggregates and DOM derived from each of the macrophytes were fed during 5 separate trials. During 3 additional trials, we fed scallops morphous detritus derived from each macrophyte for the same length of time as the corresponding aggregate and DOM diets. After the feeding period, scallops were kept in FSW in the flow-through system with no food for $48 \mathrm{~h}$ to allow them to flush unincorporated ${ }^{15} \mathrm{~N}$, and then they were dissected and their tissues analyzed for ${ }^{15} \mathrm{~N}$.

${ }^{15} \mathrm{~N}$ analysis. Samples of macrophytes, morphous detritus, aggregates and scallops were prepared for atom $\%{ }^{15} \mathrm{~N}$ measurements using a modified closed tube combustion method (Dumas procedure). Dried samples, ground with a Wig-L-Bug (Crescent Dental), were placed into $9 \mathrm{~mm}$ o.d. Pyrex tubes containing pre-combusted calcium oxide, cupric oxide and copper. Tubes were evacuated onto a vacuum line, dosed with 500 mTorr of analytical grade neon, and sealed. Tubes were combusted at $550^{\circ} \mathrm{C}$ for $12 \mathrm{~h}$ in a muffle furnace, and allowed to equilibrate for at least $24 \mathrm{~h}$. The atomic emission spectra of the $\mathrm{N}_{2}$ gas in the sealed tubes were measured with a Jasco NIA-1 spectrometer (Easton, MD, USA). Measurements made on this instrument have a precision of 0.02 atom $\%{ }^{15} \mathrm{~N}$.

Atom $\%{ }^{15} \mathrm{~N}$ of DOM was not measured directly, as the dry combustion method cannot be used on soluble material (although see Bronk \& Glibert 1991). Since the DOM treatment diets were prepared from the filtrate of the corresponding aggregate treatments, we used the atom $\%{ }^{15} \mathrm{~N}$ measured in aggregates in our calculations of $\mathrm{N}$ incorporation by DOM-fed scallops. This assumes that there were no other sources of DON in the aggregate treatments and that no appreciable $\mathrm{N}$ fractionation occurred during the process of aggregate formation. Note that it is extremely unlikely that any fractionation would be large enough to significantly affect our calculated rates of $\mathrm{N}$ incorporation.

Scallop adductor muscle tissue was analyzed for atom $\%{ }^{15} \mathrm{~N}$ separately from the rest of the body tissue to avoid a potential problem resulting from ${ }^{15} \mathrm{~N}$ being ingested but not assimilated by the animals. Measured
${ }^{15} \mathrm{~N}$ in muscle tissue was highly correlated with that measured in the rest of the body $(\mathrm{r}=0.91, \mathrm{n}=55, \mathrm{p}<$ 0.001 ), so only data for body atom $\%{ }^{15} \mathrm{~N}$ are presented here.

The amount of nitrogen incorporated by scallops fed labelled diets was calculated as:

$$
\begin{array}{r}
\text { specific } \mathrm{N} \text { uptake } \times \text { scallop } \% \mathrm{~N} \times 10^{6} \mu \mathrm{g} \\
\text { hours fed diet } \times 1 \mathrm{~g} \\
=\mu \mathrm{g} N \text { incorporated } \mathrm{g}^{-1} \text { dry wt } \mathrm{h}^{-1}
\end{array}
$$

where specific $\mathrm{N}$ uptake was calculated as:

$$
\frac{\text { atom } \%{ }^{15} \mathrm{~N}_{\text {treatment scallop }} \text { - atom } \%{ }^{15} \mathrm{~N}_{\text {unted control scallop }}}{\text { atom } \%{ }^{15} \mathrm{~N}_{\text {treatment diet }} \text { - atom } \%{ }^{15} \mathrm{~N}_{\text {treatment scallop }}}
$$

This calculation was only made for those treatments where the atom $\%{ }^{15} \mathrm{~N}$ of scallops fed the given diet was statistically different from unfed controls ( $t$-test), thus making the numerator greater than zero.

The \% $\mathrm{N}$ of 3 randomly chosen scallops fed aggregates produced from each of the 5 macrophytes was measured with a Perkin-Elmer Model 240C CHN analyzer, with acetanilide as the standard. There were no differences in $\% \mathrm{~N}$ among scallops fed different diets, so the overall average $\% \mathrm{~N}(8.99 \pm 0.16, \mathrm{SE})$ was used in Eq. (1).

\section{RESULTS}

Macrophytes, leached macrophytes, and the aggregates formed from macrophyte leachate were all well labelled with ${ }^{15} \mathrm{~N}$ (Table 1), confirming that the nitrogen originally in the producers was released as DOM and subsequently converted into aggregate nitrogen.

Table 1. Atom $\%{ }^{15} \mathrm{~N}( \pm \mathrm{SE})$ of initial and leached macrophytes and aggregates formed by bubbling the leachate released by these species. Numbers in parenthesis indicate the num-

\begin{tabular}{|c|c|c|c|}
\hline Species & $\begin{array}{c}\text { Initial } \\
\text { macrophyte }\end{array}$ & $\begin{array}{l}\text { Leached } \\
\text { macrophyte }\end{array}$ & Aggregates \\
\hline $\begin{array}{l}\text { Fucus } \\
\text { vesiculosis }\end{array}$ & $20.4 \pm 2.1(2)$ & $15.7 \pm 1.8$ & $24.4 \pm 1.9(3)$ \\
\hline $\begin{array}{c}\text { Gracilaria } \\
\text { tikvahiae }\end{array}$ & $19.7 \pm 3.7$ & $14.2 \pm 1.3(4)$ & $28.7 \pm 0.2(2)$ \\
\hline $\begin{array}{l}\text { Spartina } \\
\text { alterniflora }\end{array}$ & 11.0 & $9.8 \pm 0.7(4)$ & 9.6 \\
\hline $\begin{array}{l}\text { Ulva } \\
\text { lactuca }\end{array}$ & 24.7 & $19.8 \pm 2.1(3)$ & $25.6 \pm 11(3)$ \\
\hline $\begin{array}{c}\text { Zostera } \\
\text { marina }\end{array}$ & $27.7 \pm 0.3(2)$ & $22.8 \pm 1.4(4)$ & $26.1 \pm 0.4(2)$ \\
\hline
\end{tabular}
ber of replicates analyzed. Atom $\%{ }^{15} \mathrm{~N}$ of the DOM diet was assumed equivalent to that of aggregates (see text) 
The atom $\%{ }^{15} \mathrm{~N}$ of the leached macrophytes was always less, while that of the aggregates was usually greater, than that of labelled macrophytes. Since macrophytes were dosed with ${ }^{15} \mathrm{~N}$ for periods of weeks to months, the more labile pools of $\mathrm{N}$ were probably better labelled than structural nitrogen pools that turn over more slowly. The decrease in atom $\%{ }^{15} \mathrm{~N}$ after leaching implies that ${ }^{15} \mathrm{~N}$-rich material was preferentially released into the dissolved pool. This is consistent with the fact that the atom $\%{ }^{15} \mathrm{~N}$ of aggregates was usually greater than that of the macrophytes.

Scallops fed morphous detritus or DOM diets incorporated very little ${ }^{15} \mathrm{~N}$. In fact, their atom $\%{ }^{15} \mathrm{~N}$ values were usually not high enough to distinguish fed scallops from unfed controls. This was true for scallops fed morphous detritus derived from all 5 macrophytes, and also for scallops fed DOM derived from Spartina alterniflora, Zostera marina, or Ulva lactuca (individual t-tests comparing unfed controls and morphous-fed or DOM-fed scallops within each experimental trial were not significant). Scallops fed DOM derived from Fucus vesiculosis or Gracilaria tikvahiae did incorporate measurable quantities of ${ }^{15} \mathrm{~N}$, so nitrogen incorporation rates could be calculated for these experiments using Eq. (1) (Table 2). Scallops fed Fucus-derived DOM incorporated $24 \%$, and those fed Gracilaria-derived DOM incorporated $13 \%$ of the amount incorporated by scallops fed aggregates derived from $F$. vesiculosis and G. tikvahiae, respectively.

The atom $\%{ }^{15} \mathrm{~N}$ of scallops fed aggregates was always significantly greater than that of starved controls (individual $t$-tests between aggregate-fed and unfed controls within a trial were significant; $\mathrm{p}<$ 0.001 ), and these data were used to calculate $\mathrm{N}$ incorporation rates (Table 2). In every case, aggregate $\mathrm{N}$ was incorporated at higher rates than $\mathrm{N}$ from morphous or DOM treatment diets, suggesting that aggregates are a higher quality food source than either of

Table 2. Nitrogen incorporation ( $\mu \mathrm{g} \mathrm{N} \mathrm{g} \mathrm{g}^{-1}$ dry $w \mathrm{~h}^{-1}, \pm \mathrm{SE}$ ) by scallops Argopecten irradians fed morphous detritus, DOM or aggregates derived from each of the macrophyte species listed below. Numbers in parenthesis indicate the number of replicate scallops fed each treatment. ' $<$ ' denotes below detection limit

\begin{tabular}{|lccc|}
\hline Species & \multicolumn{3}{c|}{ Treatment diet } \\
& $\begin{array}{c}\text { Morphous } \\
\text { detritus }\end{array}$ & DOM & Aggregates \\
\hline Fucus vesiculosis & $<(5)$ & $20 \pm 4(9)$ & $84 \pm 6(9)$ \\
Gracilaria tikvahiae & $<(6)$ & $15 \pm 5(6)$ & $108 \pm 17(6)$ \\
Spartina alterniflora & $<(6)$ & $<(2)$ & $133 \pm 28(6)$ \\
Ulva lactuca & $<(6)$ & $<(6)$ & $111 \pm 11(16)$ \\
Zostera marina & $<(6)$ & $<(3)$ & $56 \pm 11(3)$ \\
\hline
\end{tabular}

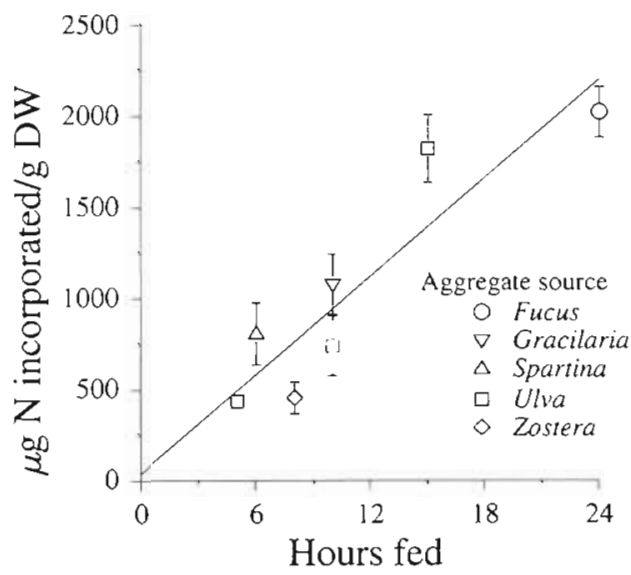

Fig. 2. Argopecten irradians. Weight-specific nitrogen incorporation (mean $\pm \mathrm{SE}$ ) by scallops that were fed aggregates derived from 5 different species of macrophytes (Fucus vesiculosis, Gracilaria tikvahiae, Spartina alterniflora, Ulva lactuca, and Zostera marinal versus the number of hours scallops were fed the ${ }^{15} \mathrm{~N}$-labelled material. Symbols represent values for aggregates from each macrophyte, as shown on the figure. Line equation is: $\mu \mathrm{g} \mathrm{N}$ incorporated $\mathrm{g}^{-1}$ dry wt $=90 \times$ No. of hours fed diet $+36, r^{2}=0.87, p<0.001$

the other 2 detrital diets. In addition, $N$ uptake was linearly related to the amount of time scallops were fed labelled aggregates $\left(\mathrm{r}^{2}=0.87, \mathrm{p}<0.001\right.$; Fig. 2$)$. This was true despite the fact that data were combined from different trials, using different species of macrophytes to produce aggregates, and feeding for varying lengths of time, and provides evidence that scallops incorporated similar amounts of nitrogen when fed aggregates regardless of the macrophyte source of the DOM.

\section{DISCUSSION}

The transfer of ${ }^{15} \mathrm{~N}$ from macrophytes to aggregates and then to scallops observed in these experiments demonstrates that macrophyte-released DOM was converted to aggregates that were in turn incorporated by consumers. These results are consistent with our previous reports that aggregates were not only incorporated by other metazoan consumers, but were a better diet than either morphous detritus or DOM (D'Avanzo \& Valiela 1990 versus D'Avanzo et al. 1991, Alber \& Valiela 1994c). In fact, aggregates had both more protein ( 12 to $27 \%$ vs 5 to $12 \%$ ) and lower C:N ratios (4 to 8 vs 13 to 35 ) than morphous detritus (Alber \& Valiela 1994b), suggesting the 2 diets are qualitatively different. The DOM diet also differed in quality from aggregates: the carbohydrate:protein ratios of DOM derived from these 5 macrophytes varied widely $(0.5$ to 95$)$ whereas those of aggregates did not $(0.4$ to 
1: Alber \& Valiela 1994 b). There have been very few other studies that compared these different detrital diets, but tadpoles Bufo americanus survived better when fed aggregates than when fed morphous detrital particles (Bowen 1984, Ahlgren \& Bowen 1991).

Scallops incorporated aggregates produced from the different macrophyte species equally well, as demonstrated by the linear relationship between feeding time and nitrogen incorporation observed in Fig. 2. Although this observation is contrary to our original expectation that the source of DOM would influence aggregate incorporation, it is consistent with other results from our experimental system. Namely, aggregates produced from the DOM of these same 5 macrophytes all had large numbers of bacteria and were biochemically similar both to each other and to bacteria (Alber \& Valiela 1994a, b). The fact that scallops could not distinguish between aggregates produced from different macrophytes is therefore in keeping with our hypothesis, set forth in Alber \& Valiela (1994a), that aggregates are largely microbial in nature.

When taken together, these results provide evidence that microbial organic aggregates can be a route for the flow of material from macrophytes to suspension feeders in coastal marine systems. In fact, the aggregate pathway has been proposed as a generalized route by which labile DOM from any source can be used by consumers in aquatic environments (Bowen 1984, Mann 1988, Wotton 1988). The first step in this pathway, transformation of DOM to aggregates, is one that has been examined by several investigators [e.g. Biddanda (1985) formed microbial organic aggregates from phytoplankton exudate that look similar to those described here], and it is generally accepted that one of the fates of DOM in aquatic systems is transforma- tion into POM, via either biological or physico-chemical mechanisms (for several general reviews, see Wotton 1990).

The second step, consumption of aggregates by consumers, is one that has not been as well studied. However, several other studies do provide evidence for the hypothesis that amorphous aggregates can be a food source for metazoans. Baylor \& Sutcliffe (1963) grew brine shrimp Artemia salina on aggregates made from DOM in seawater. Corner et al. (1974) found that overwintering copepods Calanus helgolandicus sustained body nitrogen when fed particulate material produced in a foam-tower by bubbling seawater enriched with soluble extracts of phytoplankton, but not when fed suspended matter collected from the water. Camilleri \& Ribi (1986) successfully fed 'flakes' produced from DOM released by mangrove leaves to several metazoan consumers. In freshwater, Rounick \& Winterbourn (1983) showed that several common invertebrates could feed on 'heterotrophic layers' that formed in the presence of leachate on stone surfaces in streams. More recently, Couch (1994) demonstrated that blackfly Sumilum sp. larvae could grow on aggregates precipitated from the DOC in a blackwater river.

In Fig. 3 we present a conceptual model for detrital food webs that delineates the various pathways by which primary producer carbon can be incorporated by metazoan consumers. This model does not attempt to describe feedbacks in detrital systems (e.g. the release of DOM by bacteria and consumers is not depicted), but rather to provide a framework for detrital food webs that distinguishes between morphous and amorphous detritus and includes organic aggregates as a trophic link between primary producers and metazoan consumers. This model focuses on the actual

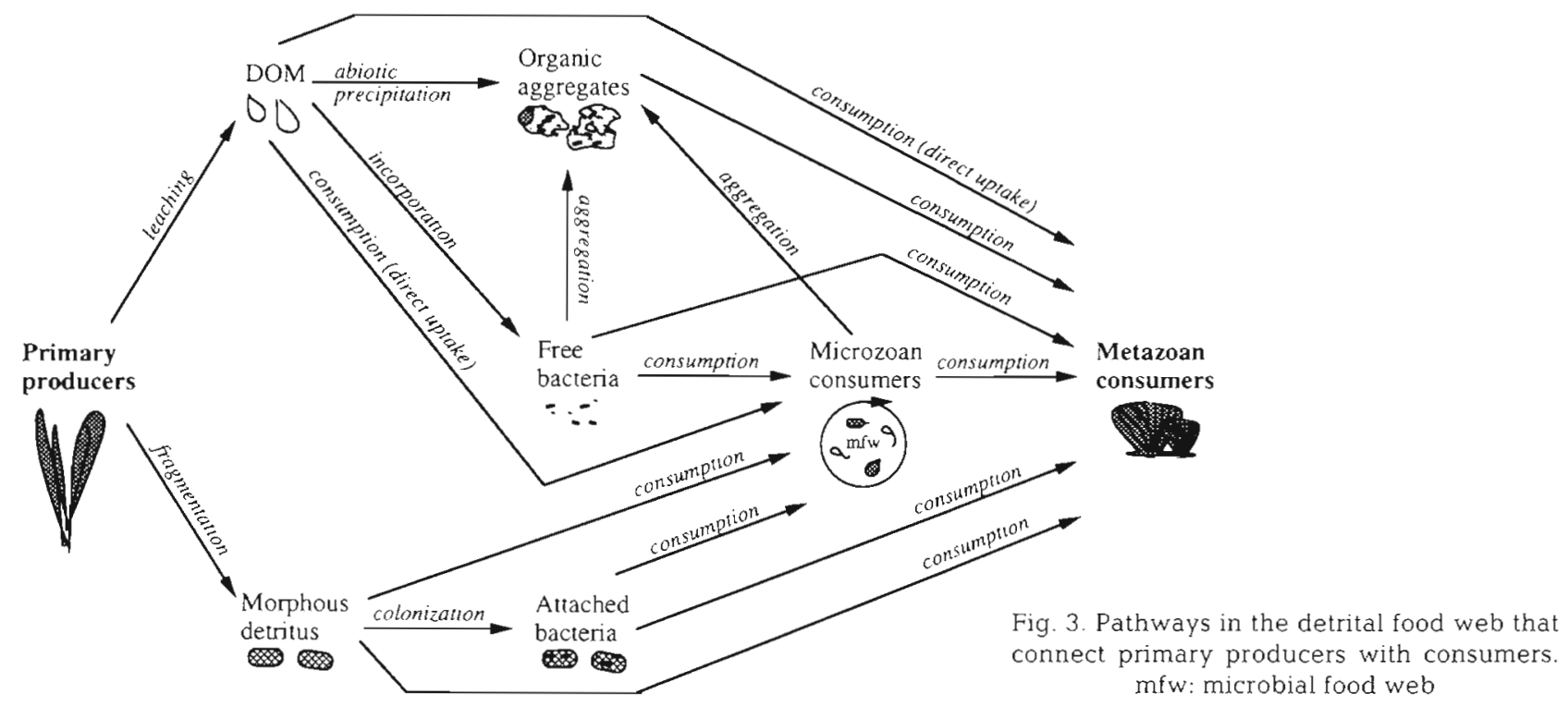


particle ingested by the consumer, which may comprise a combination of materials (e.g. a morphous detrital particle colonized by bacteria). Although the carbon that ultimately reaches the consumer is derived either from DOM, morphous detritus, bacteria, or microzoans, an aggregate that consists of bacteria, various microzoa and DOM may be more readily ingested by a larger consumer than any of the individual components.

It has not been possible to trace the aggregate pathway in the field, because of the difficulty of determining the origin of a field-collected aggregate. However, if the DOM pathways of detritus utilization are more important than the better-studied morphous detritus pathways, as our results suggest, then this may provide the explanation for why both stable isotope signatures and whole system budgets suggest that macrophyte carbon is being assimilated by consumers, despite the fact that morphous detritus is poor quality food (see 'Introduction'). Some ancillary evidence for this assertion comes from a stable isotope study of Puget Sound (Washington, USA). Simenstad \& Wissmar (1985) found that the most important sources of organic carbon to primary and secondary consumers originated primarily from eelgrass, epiphytes, and macroalgae. Since the DOC and POC associated with surface foam had isotopic values similar to both macroalgae and consumers, they suggest that foam originates from DOC excreted by highly productive macrophytes in the estuary (species of Ulva, Zostera and Enteromorpha), and that the transformation of this material to POC may be a significant food web pathway in estuarine and near-shore habitats. This notion is supported by the data presented in this paper, which provide direct evidence that producer $\mathrm{N}$ can be incorporated by consumers fed DOM aggregates.

Acknowledgements. We thank D. Caron, J. McDowell, L Pomeroy, and 2 anonymous reviewers for comments on the manuscript. S. Englestein, A. McKnight, and S. Heinser provided laboratory assistance; R. Karney of the Martha's Vineyard Shellfish Hatchery generously provided juvenile scallops. This research was supported by NOAA Sea Grant NA86-AA-DSG090, Woods Hole Oceanographic Institution Sea Grant Project R/A-24

\section{LITERATURE CITED}

Ahlgren MO, Bowen SH (1991) Growth and survival of tadpoles (Bufo americanus) fed amorphous detritus derived from natural waters. Hydrobiologia 218:49-51

Alber M, Valiela I (1994a) Production of microbial organic aggregates from macrophyte-derived dissolved organic material. Limnol Oceanogr 39:37-50

Alber M, Valiela I (1994b) Biochemical composition of organic aggregates produced from marine macrophyte-derived dissolved organic matter. Limnol Oceanogr 39:717-723

Alber M, Valiela I (1994c) Incorporation of organic aggregates by marine mussels. Mar Biol 121:259-265

Baylor ER, Sutcliffe WH (1963) Dissolved organic matter in seawater as a source of particulate food. Limnol Oceanogr 8:369-371

Biddanda BA (1985) Microbial synthesis of macroparticulate matter. Mar Ecol Prog Ser 20:241-251

Bowen SH (1984) Evidence of a detritus food chain based on consumption of organic precipitates. Bull mar Sci 35: $440-448$

Bronk DA, Glibert PM (1991) A ${ }^{15} \mathrm{~N}$ tracer method for the measurement of dissolved organic nitrogen release by phytoplankton. Mar Ecol Prog Ser 77:171-182

Camilleri JC, Ribi G (1986) Leaching of dissolved organic carbon (DOC) from dead leaves, formation of flakes from DOC, and feeding on flakes by crustaceans in mangroves. Mar Biol 91: 337-344

Corner EDS, Head RN, Kilvington CC, Marshall SM (1974) On the nutrition and metabolism of zooplankton. IX. Studies relating to the nutrition of over-wintering Calanus. J mar biol Ass UK 54:319-331

Couch CA (1994) Trophic significance of bacterial extracellular polysaccharides and dissolved organic matter in a blackwater river. PhD dissertation, University of Georgia, Athens

Cranford PJ, Grant J (1990) Particle clearance and absorption of phytoplankton and detritus by the sea scallop Placopecten magellanicus (Gmelin). J exp mar Biol Ecol 137: $105-121$

Crosby MP, Langdon CJ, Newell RIE (1989) Importance of refractory plant material to the carbon budget of the oyster Crassostrea virgunica. Mar Biol 100:343-352

Crosby MP, Newell RIE Langdon CJ (1990) Bacterial mediation in the utilization of carbon and nitrogen from detrital complexes by Crassostrea virginica. Limnol Oceanogr 35: $625-639$

D'Avanzo CD, Alber M, Vallela I (1991) Nitrogen assimilation from amorphous detritus by two coastal consumers. Estuar coast Shelf Sci 33:203-209

D'Avanzo C, Valiela I (1990) Use of detrital foods and assimilation of nitrogen by coastal detritivores. Estuaries 13: $20-24$

Duggins DO, Simenstad CA, Estes JA (1989) Magnification of secondary production by kelp detritus in coastal marine ecosystems. Science 245:170-173

Kirby-Smith W (1976) The detritus problem and the feeding and digestion of an estuarine organism. In: Wiley $M$ (ed) Estuarine processes. Academic Press, New York, p $469-479$

Kreeger CJ, Langdon DA, Newell RIE (1988) Utilization of refractory cellulosic carbon derived from Spartina alterniflora by the ribbed mussel Geukensia demissa. Mar Ecol Prog Ser 42:171-179

Langdon CJ, Newell RIE (1990) Utilization of detritus and bacteria as food sources by two bivalve suspension-feeders, the oyster Crassostrea virginica and the mussel Geukensia demissa. Mar Ecol Prog Ser 58:299-310

Mann KH (1988) Production and use of detritus in various freshwater, estuarine, and coastal marine ecosystems. Limnol Oceanogr 33:910-930

Newell RC, Field JG, Griffiths CL (1982) Energy balance and significance of microorganisms in a kelp bed community. Mar Ecol Prog Ser 8:103-113

Peterson BJ, Howarth RW, Garritt RH (1985) Multiple stable isotopes used to trace the flow of organic matter in estuarine food webs. Science 227:1361-1363

Rounick JS, Winterbourn MJ (1983) The formation, structure and utilization of stone surface organic layers in two New 
Zealand streams. Freshwat Biol 13:57-72

Seiderer LJ, Newell RC (1985) Relative significance of phytoplankton, bacteria and plant detritus as carbon and nitrogen resources for the kelp bed filter-feeder Choromytilus meridionalis. Mar Ecol Prog Ser 22:127-139

Simenstad CA, Duggins DO, Quay PD (1993) High turnover of inorganic carbon in kelp habitats as a cause of $\delta^{13} \mathrm{C}$ variability in marine food webs. Mar Biol 116:147-160

Simenstad CA, Wissmar RC $(1985){ }^{13} \mathrm{C}$ evidence of the origins and fates of organic carbon in estuarine and nearshore food webs. Mar Ecol Prog Ser 22:141-152

Stuart V, Field JG, Newell RC (1982) Evidence for absorption of kelp detritus by the ribbed mussel Aulacomya ater using a new ${ }^{51} \mathrm{Cr}$-labelled microsphere technique. Mar Ecol Prog Ser 9:263-271

Tenore KR (1977) Growth of Capitella capitata cultured on various levels of detritus derived from different sources.

This article was presented by D. A. Caron (Senior Editorial Advisor), Woods Hole, Massachusetts, USA
Limnol Oceanogr 22:936-941

Tenore KR, Hanson RB (1980) Availability of detritus of different types and ages to a polychaete macroconsumer, Capitella capitata. Limnol Oceanogr 25:553-558

Van Valkenberg SD, Jones JK, Heinle DR (1978) A comparison by size class and volume of detritus versus phytoplankton in Chesapeake Bay. Estuar coast mar Sci 6:569-582

Williams P (1981) Detritus utilization by MytiJus edulis. Estuar coast Shelf Sci 12:739-746

Winter JE (1978) A review of the knowledge of suspensionfeeding in lamellibranchiate bivalves, with special reference to artificial aquaculture systems. Aquaculture 13: $1-33$

Wotton RS (1988) Dissolved organic material and trophic dynamics. BioSci 38:172-178

Wotton RS (1990) The biology of particles in aquatic systems. CRC Press, Boca Raton

Manuscript first received: June 29, 1994

Revised version accepted: January 6, 1995 